\title{
Effects of benzo[a]pyrene on the blood and liver of Physalaemus cuvieri and Leptodactylus fuscus (Anura: Leptodactylidae)
}

\author{
Lara Zácari Fanali a, * , Lilian Franco-Belussi b, c, Cláudia Regina Bonini-Domingos b', \\ Classius de Oliveira ${ }^{\text {b }}$ \\ a Graduate Program in Animal Biology, Universidade Estadual Paulista (UNESP), São José do Rio Preto, São Paulo, 15054-000, Brazil \\ b Department of Biology, Universidade Estadual Paulista (UNESP), São José do Rio Preto, São Paulo, 15054-000, Brazil \\ ${ }^{\mathrm{c}}$ Graduate Program in Biotechnology and Environmental monitoring, CCTS, Federal University of São Carlos, 18052-780, Sorocaba, São Paulo, Brazil
}

\section{A R T I C L E I N F O}

\section{Article history:}

Received 15 September 2017

Received in revised form

13 January 2018

Accepted 9 February 2018

Available online 22 February 2018

\section{Keywords:}

Anuran

Liver melanomacrophage

Leukocytes

Erythrocytes

Micronuclei

\begin{abstract}
A B S T R A C $T$
Benzo[a]pyrene (BaP) is a bio-accumulative toxic compound found in the atmosphere, water, and soil that may affect the life cycle of amphibians. In this study, a few contamination biomarkers, such as hepatic melanomacrophages (MMs), mast cells, erythrocyte micronuclei (MN) and white blood cells were used to determine how BaP acts in these cells in the anurans Physalaemus cuvieri and Leptodactylus fuscus. Animals of both species were divided into three treatment groups: 1 day, 7 days and 13 days, subcutaneously injected $2 \mathrm{mg} / \mathrm{kg} \mathrm{BaP}$ diluted in mineral oil and control group with only mineral oil. After 7 days, BaP caused the frequency of MN to increase in both species while reducing melanin area. The micronucleus frequency increased due to the genotoxicity of BaP, while the decreasing melanin area may be related to the inhibition of tyrosinase activity, an enzyme responsible for regulating melanogenesis, decreasing the synthesis of melanin. The mast cell density increased in all groups and in both species as a response to the inflammatory action of BaP. These cells respond to nonspecific inflammatory effects leading, therefore, to this response in all treatments. The percentage of leukocytes remained unchanged probably due to great intraspecific variability. Additionally, the leukocyte profiles of both species were characterized and the differences were attributed to extrinsic factors. In short, BaP can affect the integrity of several organs and tissues, and cell functions leading to the conclusion that this compound is hepatotoxic, genotoxic and immunotoxic for anurans.
\end{abstract}

๑) 2018 Elsevier Ltd. All rights reserved.

\section{Introduction}

In recent years, the number of ecotoxicological studies on amphibians has grown rapidly (Burlibaşa and Gavrilă, 2011), justified by a few peculiar characteristics of this taxon. These animals are very sensitive to pollutants, due to characteristics such as skin permeability, water-dependent reproduction, exposed embryogenesis, and a life-cycle that is dependent on both aquatic and terrestrial environments, thus maximizing their exposure to contaminants (Conrad, 2010; Burlibașa and Gavrilă, 2011; Blaustein et al., 2011; Pérez-Iglesias et al., 2016; De Oliveira et al., 2017).

Contaminants such as chemical pollutants are distributed in the

\footnotetext{
* Corresponding author. Department of Biology, Instituto de Biociências, Letras e Ciências Exatas, Universidade Estadual Paulista, São José do Rio Preto, São Paulo, Brazil.

E-mail address: lara_zacari@hotmail.com (L.Z. Fanali).
}

organisms through blood flow (WHO, 1995) and exposure can, therefore, induce nuclear abnormalities such as the formation of micronuclei, which consists of chromosomal fragments or whole chromosomes in anaphase (Fortin et al., 2015). Micronuclei were detected in mature erythrocytes of different fish species (Pastore et al., 2014) and amphibians when exposed to BaP or pesticides, for example (Grinfeld et al., 1986; Candioti et al., 2010; PérezIglesias et al., 2014). Hematological parameters can also be affected, due to the exposure to contaminants (Winkaler et al., 2008). These changes of the physiological status provide information on the level of damage, indicating the healthy status of anurans and other animals (Sayed, 2015). In this context, differential leukocyte count also provides information on the immunological status (Newman et al., 1997).

In addition to micronuclei formation and quantitative changes of leukocytes, melanomacrophages and mast cells are also responsive to the action of xenobiotics (Ma et al., 2011; Franco- 
Belussi et al., 2013, 2016; Möller et al., 2014; Passantino et al., 2014; Çakıc1, 2015; Regnault et al., 2014, 2016). For this reason, these cells are used, respectively, as contamination biomarkers and inflammatory response indicators in several tissues (Paetow et al., 2012; Franco-Belussi et al., 2013; Santos et al., 2014).

Melanomacrophages are macrophages that produce and store pigments such as melanin, lipofuscin, and hemosiderin (Agius and Roberts, 2003; Ribeiro et al., 2011). Melanin, the major pigment of this phagocytic cell absorbs and neutralizes free radicals, cations and other potentially toxic agents derived from the degradation of phagocytized cellular material (Zuasti et al., 1989). These cells are found in hematopoietic organs such as liver and spleen (Agius, 1980; Cesarini, 1996) of ectothermic animals (fish, amphibians, and reptiles) (Wolke, 1992; Fournie et al., 2001; Loumbourdis and Vogiatzis, 2002; Fishelson, 2006) while having detoxification, bactericidal and innate immunity as main functions (Agius and Roberts, 2003; Passantino et al., 2014; Franco-Belussi et al., 2013). Mast cells specialize in secreting mediators of lipids, leukotrienes, proteases, and histamine, which contribute to the inflammatory process (Shakoory et al., 2004) while playing an important role in inflammatory response mechanisms associated with a wide range of stress conditions, such as exposure to xenobiotics (Lauriano et al., 2012).

Polycyclic Aromatic Hydrocarbons (PAHs) are highly studied toxic compounds due to its toxicity at low and moderate concentrations, and its persistence in the environment (Brandt et al., 2002). Benzo[a]pyrene (BaP) is considered a high-risk contaminant due to genotoxicity (Mouchet et al., 2005) and ability to induce micronucleus formation in erythrocytes (Fortin et al., 2015), hepatotoxicity (Latif et al., 2010; Regnault et al., 2014, 2016; Pastore et al., 2014), immunotoxicity (Phalen et al., 2014) and also change the patterns of the leukocyte cells (Sorensen, 1991; Sayed, 2015). Because it results from the incomplete combustion of organic matter, it can be present naturally in fires (Zakaria et al., 2002; Ou et al., 2004; Luo et al., 2008; Jiao et al., 2009) or result from anthropogenic action, such as the use of oil products and fossil fuel combustion (Zakaria et al., 2002; Kim et al., 2008; Morillo et al., 2008; Stogiannidis and Laane, 2015).

$\mathrm{BaP}$ is adsorbed by particles present in water, suspended in the air (WHO, 1998; Srogi, 2007), in sediments and in the soil (Stark et al., 2003; Morillo et al., 2008; Harris et al., 2011). Because it is practically everywhere, anurans may be exposed to it via inhalation, feeding and through the skin (Collins et al., 1991; Kanaly and Harayama, 2000). In addition, this compound may bioaccumulate in anurans (Brandt et al., 2002), becoming quite harmful since after its absorption, BaP is biotransformed in the liver by the cytochrome P450 1A1 (CYP1A1) (Caruso and Alaburda, 2008; Wakx et al., 2016). Throughout its metabolism, toxic byproducts are formed, especially the 7,8-dihydroxy-9,10-epoxy-7,8,9,10-tetra (a) pyrene (BPDE) (Madureira et al., 2014).

Although toxic compounds are produced during BaP metabolism and disrupt homeostasis (Chovatiya and Medzhitov, 2014), anurans have defense cells such as melanomacrophages, mast cells, and leukocytes, which are capable of attenuating toxicity, due to their functions. The consequence of the protective response of these cells is the homeostasis restoration (Chovatiya and Medzhitov, 2014), enabling the survival and adaptation of the animals in anthropic environments (Blaustein et al., 2011). In general, the effects of pollutants on the internal morphology of adult anurans are poorly known (Fanali et al., 2017). After undergoing biotransformation in the liver, the metabolites of BaP reach target organs through circulation, causing toxicity (Van Veld et al., 1988; Buhler and Williams, 1988; Costa et al., 2011; Fanali et al., 2017). Therefore, the purpose of the study was to determine the effects of $\mathrm{BaP}$ on hepatic melanomacrophages, hepatic mast cells, leukocyte composition and erythrocytes integrity of the of $P$. cuvieri and L. fuscus.

During its reproductive period, $P$. cuvieri performs mating vocalization in newly flooded environments, usually inside animal footprints, when deep and filled with water (Uetanabaro et al., 2008), while L. fuscus vocalizes on the ground, on the banks of temporary ponds or depressions subject to flooding (Uetanabaro et al., 2008). Both species coexist, have similar living habits, and are phylogenetically close and abundant in the study region. Because these two species share the same habitat and expose themselves to similar environmental conditions, they could be used as sentinel species to evaluate the cause-effect relationships of chemical contaminants in the environment.

\section{Material and methods}

\subsection{Animal sampling}

Seventy-two adult males, 36 P. cuvieri and 36 L. fuscus, were used in the experiment. This project was approved by the Ethics Committee on Animal Use, protocol 094 and RAN/IBAMA/MMA 18573-1. The animals were collected in northwestern São Paulo, Brazil, from December to February, period that includes the species reproductive season. The animals were acclimated for one week, in $28 \times 21 \times 15 \mathrm{~cm}$ boxes containing $2 \mathrm{~cm}$ of soil, which was kept moist. Room temperature was kept at $27^{\circ} \mathrm{C}$, with natural photoperiod. During the experimental period, all animals were fed with Drosophila shortly after the injections to avoid further stress.

\subsection{Experiments with benzo[a]pyrene}

The studied parameters were evaluated at 1, 7 and 13 days after all animals were subcutaneously injected $2 \mathrm{mg} / \mathrm{kg}$ benzo[a]pyrene (B1760; purchase from Sigma-Aldrich), diluted in $0.02 \mathrm{ml}$ of Nujol mineral oil, while the control consisted of mineral oil only. The solution was injected every $48 \mathrm{~h}$ on the animal back, near the hind limb. The solution concentration was adapted and based on the work of Padrós et al. (2003). The animals ( $\mathrm{N}=6$, per group) were exposed for 1,7 and 13 days and each group had its respective control with the same experimental period. This experimental model was replicated for each species.

After the experiment, the hind limb was anesthetized with xylocaine (with the excess removed with cotton to avoid smear interference) and blood was drawn from the femoral vein using a heparinized needle and a syringe. Smear was performed immediately after collection, due to the small blood sample and rapid coagulation.

The animals were then euthanized with benzocaine solution $(1 \mathrm{~g} / \mathrm{L})$ and had their liver sampled, which was weighed in an analytical balance ( $0.05 \mathrm{~g}$ precision) and analyzed as the following procedures.

\subsection{Micronucleus analysis}

After drying, slides were fixed in methanol at $4{ }^{\circ} \mathrm{C}$ for $20 \mathrm{~min}$, stained with Giemsa $7.5 \%$ for $15 \mathrm{~min}$ and observed under a light microscope (Leica DM4000 B). A total of 1000 erythrocytes were counted for each animal.

\subsection{Leukocyte analysis}

For differential leukocyte count, the blood smear was stained with Panoptic (Hematocor-Biológica ${ }^{\circledR}$ ) to identify leukocytes variety and establish their relative proportions. For each animal, 100 leukocytes were counted under a light microscope (Leica DM4000 
B). The percentage of each leukocyte type in the peripheral circulating blood was determined, and knowing the total circulating leukocytes, the percentage of each cell type was obtained.

The means of controls (1, 7 and 13 days) was calculated and used to determine the leukocyte profile and compare it in the two species.

\subsection{Histological processing}

P. cuvieri and L. fuscus liver fragments were fixed in Metacarn (60\% methanol, $30 \%$ chloroform, and $10 \%$ acetic acid) for the histological analyses. Subsequently, samples were washed in water, dehydrated in alcoholic series and placed in historesin (Leica-historesin embedding kit). The $2 \mu \mathrm{m}$ sections were obtained with the aid of a microtome (RM 2265, Leica, Switzerland), stained and observed under a light microscope (Leica DM4000 B) coupled with an image capture system (Leica DFC 280).

\subsection{Quantitative analyses}

The sections were stained with Hematoxylin-eosin and pigmentation was quantified using Image Pro-Plus program, Media-Cybernetics Inc. (version 6.0) based on the different color intensity according to Santos et al. (2014). For each animal, a slide with 20 sections was prepared, 25 random fields were photographed and the melanomacrophage melanin area was analyzed.

A solution containing $0.025 \mathrm{~g}$ toluidine blue with borax $(\mathrm{pH} 4.0)$ diluted in $50 \mathrm{ml}$ distilled water was used to detect the presence of mast cells in the liver. The sections were washed in distilled water for $1 \mathrm{~min}$, stained with toluidine blue for $30 \mathrm{~s}$, washed in distilled water, allowed to dry for assembly with Canada's balsam. Ten randomized histological sections of each animal were selected for mast cell count. The section area was quantified using the Image Pro-Plus program, Media-Cybernetics Inc. (version 6.0).

\subsection{Statistical analysis}

We used a $2 \times 3$ factorial design with two treatments (one BaP concentration and the control), crossed with three exposure times: $1 \mathrm{~d}, 7 \mathrm{~d}$, and $13 \mathrm{~d}$. We used six animals per treatment to quantify melanomacrophage area, micronucleus frequency, mast cell density and leukocyte percentage.

A Generalized Linear Model (GLM) with binomial distribution and $\log$ link function including treatment and exposure time, along with their interactions were used to model the frequency of micronucleus and leukocyte types (lymphocytes, basophils, eosinophils, monocytes, and neutrophils) (counting data). We tested the model assumptions using diagnostic plots from the $\mathrm{R}$ (Team Core, 2016) sjPlot package (Lüdecke, 2016). Residuals showed homogeneity of variance and normal distribution. The leukocyte profiles were compared between both species using the animals of the control groups. For this, a GLM was performed for each leukocyte type and modulated by the species.

To model melanomacrophage area, our continuous response variable, we fitted a Linear Mixed-Effects Model (package Ime4; Bates et al., 2015) (Zuur et al., 2009) with restricted maximum likelihood (REML; Bolker et al., 2009) including treatment and time of exposure as fixed factors, along with their interaction. The sampling units (pictures), in which we estimated our response variables, were nested within each animal (true replicate). To control for dependency among the 25 pictures from the same animal (Crawley, 2012: 703), we included a random intercept for animal (categorical with 6 levels; see Moen et al., 2016). We tested model assumptions using diagnostic plots with the R package sjPlot (Lüdecke, 2016). Residuals showed homogeneity of variance and normal distribution. We used least-squares means of the R package lsmeans (Lenth, 2016) to test for differences between treatment levels and exposure time. Models were summarized and the $P$ values estimated based on conditional $F$-tests with Kenward and Roger (1997) approximation for the degrees of freedom using sjPlot.

A Generalized Linear Mixed Model (GLMM) with binomial distribution including treatment and exposure time as fixed effects, along with their interaction, was used to model mast cell density in the hepatic tissue. A random animal intercept was included to control the dependence between the 10 sections of the same animal (categorical with 6 levels; Crawley, 2012: 703; Moen et al., 2016). The analysis was conducted in the $\operatorname{glmm} A D M B$ package (Fournier et al., 2012). We used the least squares means in the lsmeans package (Lenth, 2016) to test differences between levels of treatment factors and exposure time. All analyses were performed using software R v. 3.3.2 (R Core Team, 2016).

\section{Results}

\subsection{Benzo[a]pyrene effect on micronucleus frequency}

Benzo[a]pyrene displayed a genotoxic effect on $P$. cuvieri and L. fuscus after 7 days of exposure to the contaminant, which resulted in an increased frequency of micronucleus from $0.0 \pm 0.0$ to $0.001 \pm 0.0008(100 \%)$ in P. cuvieri and from $0.00016 \pm 0.00016$ to $0.0023 \pm 0.0012(1356 \%)$ in L. fuscus (Fig. $1 ; P<0.0001$ ).

\subsection{Benzo[a]pyrene effect on melanomacrophage}

BaP changed the melanin area present in the melanomacrophage in both species after 7 days of exposure. In P. cuvieri, the melanin area decreased approximately $42 \%$, from $2123.6 \pm 483.8$ to $1221.5 \pm 233.1(P=0.042)$ whereas in $L$. fuscus it decreased by $4125.1 \pm 934.7$ to $1474.2 \pm 236.3(P=0.042)$, corresponding to $64 \%$ (Figs. 2-4).

\subsection{Benzo[a]pyrene effect on mast cell density}

BaP changed the mast cell density of $P$. cuvieri in all groups treated with the contaminant. The densities increased from $1.8 \pm 0.7$ to $4.3 \pm 1.1$ after 1 day, from $3.7 \pm 1.0$ to $6.6 \pm 1.6$ after 7 days, and from $5.1 \pm 1.6$ to $10.6 \pm 3.3$ after 13 days of exposure $(P<0.0001)$. The densities doubled approximately for each experimental time.

The mast cell density in L. fuscus also increased in all treated groups from $0.02 \pm 0.02$ to $0.2 \pm 0.1$ after 1 day, $0.2 \pm 0.1$ to $0.6 \pm 0.2$ after 7 days, and $0.7 \pm 0.2$ to $1.9 \pm 0.4$ after 13 days, corresponding to $11.5,1.28$ and $1.65 \times$, respectively (Figs. 5 and $6 ; P<0.0001$ ).

\subsection{Leukocyte profile and benzo[a]pyrene effect on the percentage of leukocytes}

Leukocyte percentages remained unchanged in both species treated with BaP; however, the leukocyte profiles of the controls of both species differed regarding lymphocytes, neutrophils and eosinophils (Fig. 7).

\section{Discussion}

\subsection{Benzo[a]pyrene effect on micronucleus frequency}

After 7 days of exposure, the genotoxic effect of BaP was evident and resulted in increased micronucleus frequency in both species. The micronucleus test is widely used to estimate cytogenetic damage induced by physical or chemical agents (Udroiu, 2006) and 


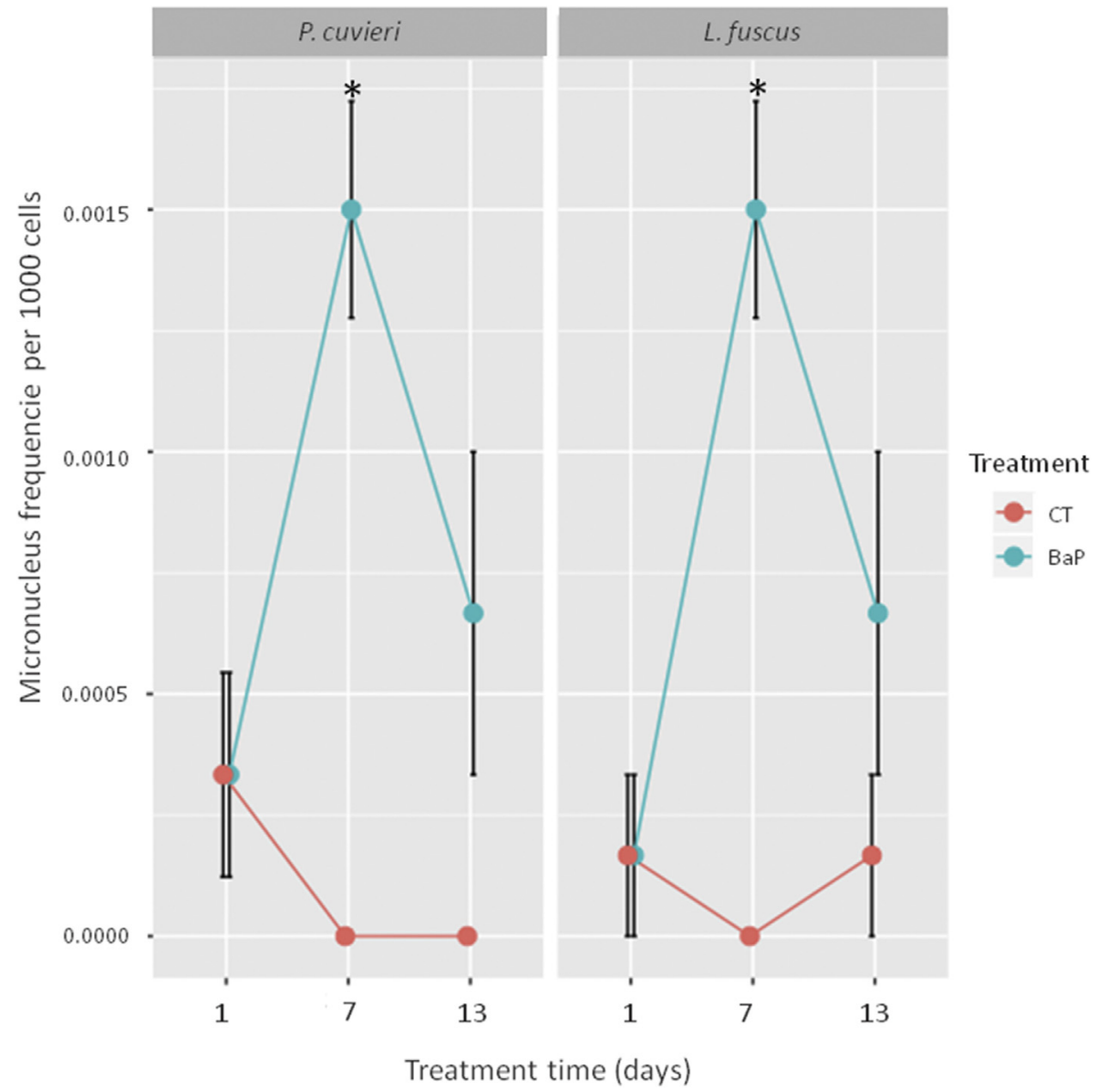

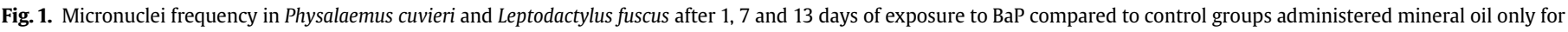
the same time intervals. The asterisk $\left(^{*}\right)$ indicates significant difference $(\mathrm{P}<0.05)$ between the control and the treated groups for the same time interval.

several studies corroborate this fact. In one of these studies, Pleurodeles walt specimens of the Urodela order were experimentally contaminated with $0.05 \mathrm{ppm}$ benzo[a]pyrene and the results showed that the micronucleus amount was time-dependent and peaked on the sixth day of treatment (Grinfeld et al., 1986).

Pérez-Iglesias et al. (2015) investigated Hypsiboas pulchellus tadpoles exposed to the herbicide imazethapyr and reported that the micronucleus frequency increased at the concentration of $1.17 \mathrm{mg} / \mathrm{L}$ after $48 \mathrm{~h}$ and for all studied concentrations (0.39, 0.78 and $1.17 \mathrm{mg} / \mathrm{L}$ ) after $96 \mathrm{~h}$. In addition, the herbicide caused other nuclear alterations such as binucleate cells and DNA damage. These responses relates to the variability of pesticide-induced toxicity in different species of amphibians. Another study reports that tadpoles had increased micronucleus after 16 days exposed to $248 \mathrm{nM}$ BaP. Micronucleus formation resulting from the exposure to the contaminant confirms the disruption of the spindle apparatus in erythrocytes. The results show that micronuclei might be useful indicators of sub-lethal effects on amphibian. Therefore, by applying these biomarkers in native species and wild populations exposed to toxicants could be valuable for investigating the causes of declining amphibian populations (Sadinski et al., 1995).

At 13 days of treatment, micronucleus frequency was lower in comparison to $7 \mathrm{~d}$. As $\mathrm{BaP}$ is a bio-accumulative toxic compound (Brandt et al., 2002) and anurans received a greater amount of it after 13 days of exposure when comparing to $7 \mathrm{~d}$, an increased frequency of MN would be expected. Pérez-Iglesias et al. (2015) revealed that $H$. pulchellus tadpoles exposed to the herbicide imazethapyr for $96 \mathrm{~h}(0.39,0.78$ and $1.17 \mathrm{mg} / \mathrm{L})$ displayed a lower micronucleus frequency in comparison to the animals that were exposed for $48 \mathrm{~h}$ (in the concentration of $1.17 \mathrm{mg} / \mathrm{L}$ ). Another insecticide, the pirimicarb, was used by Candioti et al. (2010) in Rhinella arenarum tadpoles, which also demonstrated a lower frequency of $\mathrm{MN}$ in $96 \mathrm{~h}$ when comparing to $48 \mathrm{~h}$, using concentrations of $80 \mathrm{mg} / \mathrm{L}$ and $250 \mathrm{mg} / \mathrm{L}$.

This response is supported by some hypothesis, being among them that the most damaged cells went through induced cell death by the contaminant, with less damaged erythrocytes remaining in the blood; severely damaged cells lost their division capacity, thus consequently precluding the formation of micronucleus (Candioti et al., 2010; Pérez-Iglesias et al., 2015). Both hypothesis may explain the behavior found in our study, especially when one considers the toxicological characteristics of BaP.

\subsection{Benzo[a]pyrene effect on melanomacrophages}

In both species, the melanomacrophage melanin area did not change after 1 day of exposure to BaP. However, De Oliveira et al. (2017) reported the effect of BaP, pesticides and other agrochemicals on the hepatic MMs of some anuran species for shorter exposure times. Therefore, we hypothesized that our studied time intervals were not long enough to stimulate cell response in both species at this level of histopathological evaluation. Size, rate of ingestion, growth rate, membrane permeability and ventilatory frequency are biological processes that influence PAHs absorption 


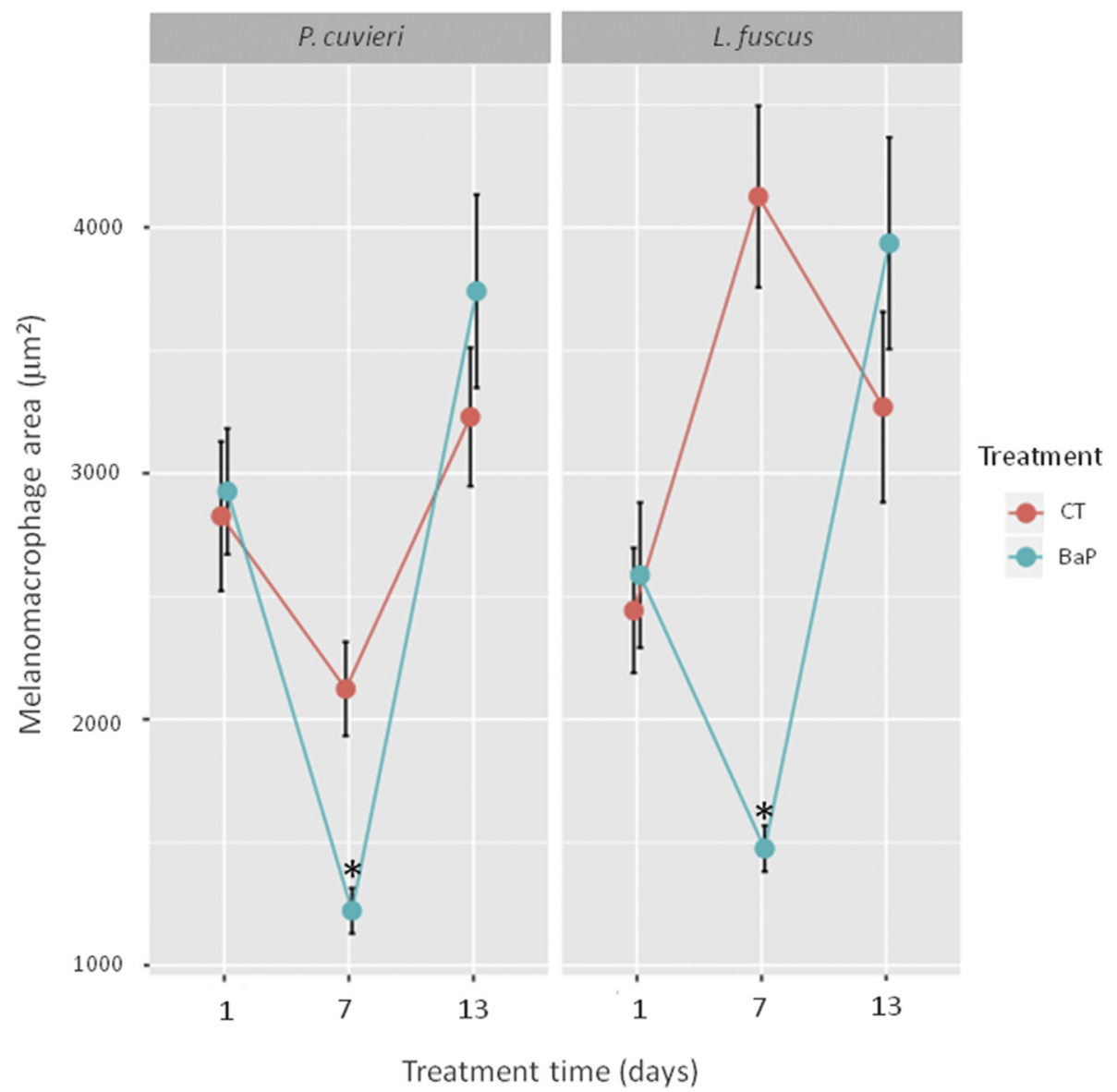

Fig. 2. Melanomacrophages area in Physalaemus cuvieri and Leptodactylus fuscus after 1, 7 and 13 days of exposure to BaP compared to control groups administered mineral oil only for the same time intervals. The asterisk $\left({ }^{*}\right)$ indicates significant difference $(\mathrm{P}<0.05)$ between the control and the treated groups for the same time interval.
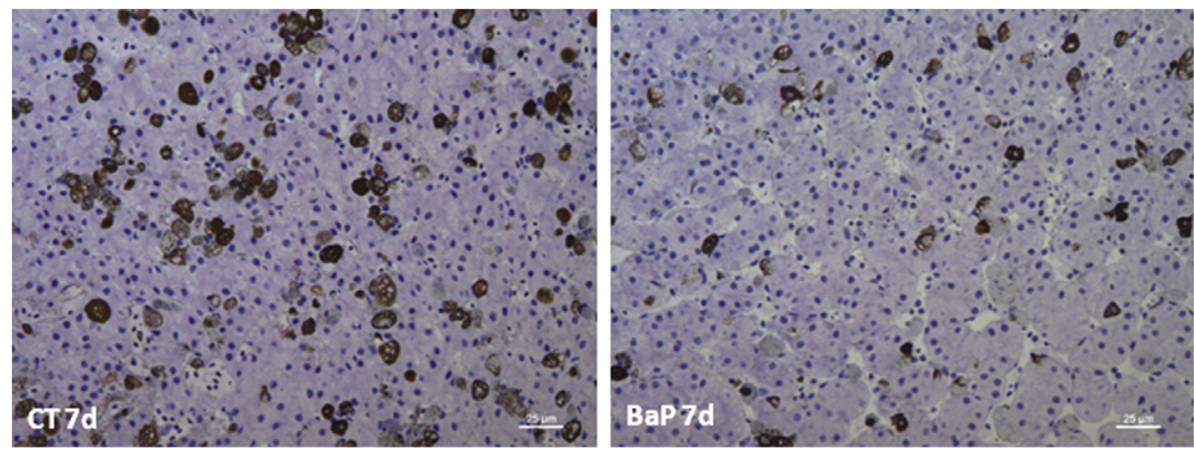

Fig. 3. Amount of melanin present in the melanomacrophages of Leptodactylus fuscus after 7 days of exposure to BaP (BaP 7d) compared to the control group treated with mineral oil only (CT 7d). It is possible to observe the decrease of the pigmented area in animals treated with BaP. Coloration: Hematoxilin-eosin.
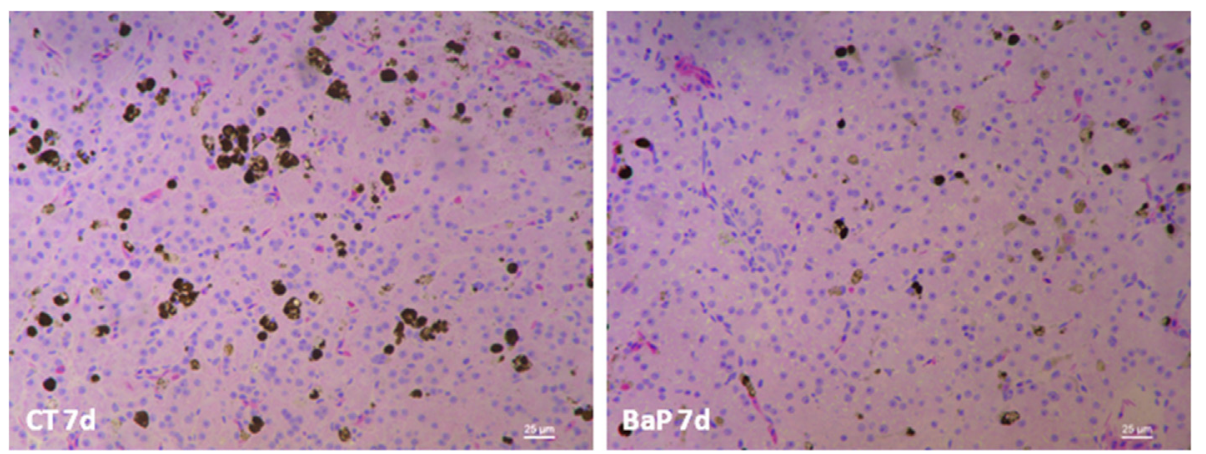

Fig. 4. Amount of melanin present in the melanomacrophages of Physalaemus cuvieri after 7 days of exposure to BaP (BaP 7d) compared to the control group treated with mineral oil only (CT 7d). It is possible to observe the decrease of the pigmented area in animals treated with BaP. Coloration: Hematoxilin-eosin. 

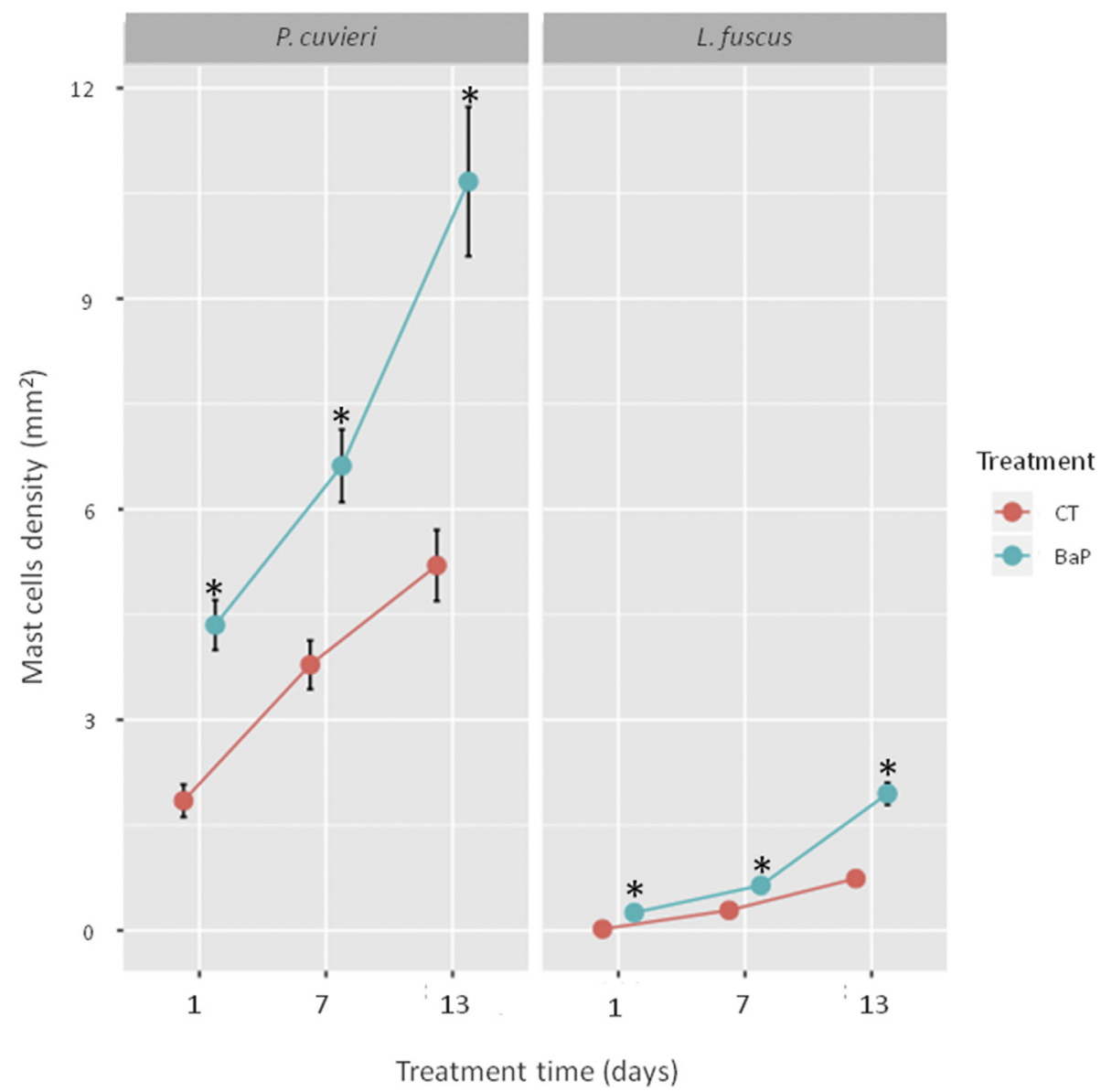

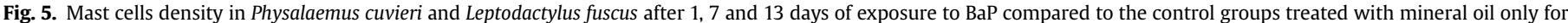
the same time intervals. The asterisk $\left({ }^{*}\right)$ indicates significant difference $(\mathrm{P}<0.05)$ between control and treated groups for the same time interval.

by the organisms (Juhasz and Naidu, 2000). We believe that these processes are influencing immediate 1-day response of the MMs in P. cuvieri and L. fuscus.

After being absorbed by the animals, BaP is biotransformed in the liver by an enzymatic class called cytochrome P450 (Caruso and Alaburda, 2008; Wakx et al., 2016). BaP induces its own biotransformation by activating the aromatic hydrocarbon receptor (AhR). The AhR is a cytosolic transcription factor that responds to environmental toxins (Sibilano et al., 2012) and, after activation, moves to the nucleus and binds to the ARNT receptor (nuclear transporter of the aryl hydrocarbon receptor). This complex binds to DNA elements that respond by regulating the expression of various genes, including genes encoding several enzymes that allow biotransformation. An example is cytochrome P450 1A1 (CYP1A1) that while metabolizing BaP, generates toxic byproducts, especially the 7,8dihydroxy-9,10-epoxy-7,8,9,10-tetra(a)pyrene (BPDE) (Madureira et al., 2014).

At 7 days, the melanin area in the hepatic melanomacrophages decreased. Regnault et al. (2014) observed a decrease in the pigmented area of MMs in Xenopus tropicalis anurans exposed to $10 \mu \mathrm{g} . \mathrm{L}^{-1}$ BaP, which remained constant after 12,18 and $24 \mathrm{~h}$ of exposure. This may be related to hepatic stress and hepatocytes apoptosis (Regnault et al., 2014). More recently, Fanali et al. (2017) also observed this same response for Hypsiboas albopunctatus anurans treated with $7 \mathrm{mg} / \mathrm{kg}$ BaP after 3 days. Melanin from pigmented cells protects adjacent tissues by absorbing potentially harmful substances and slowly releasing them at non-toxic concentrations, which results in great affinity between BaP and melanin (Larsson, 1993). However, long-term exposure may cause high levels of harmful chemicals to accumulate in the melanin, and ultimately stimulate melanin-containing cells to degenerate and secondary lesions in surrounding tissues (Larsson, 1993), thus decreasing MM area. Additionally, Joo et al. (2005) showed that BaP inhibits tyrosinase activity, the enzyme responsible for regulating melanogenesis, induced by the melanocyte stimulating hormone

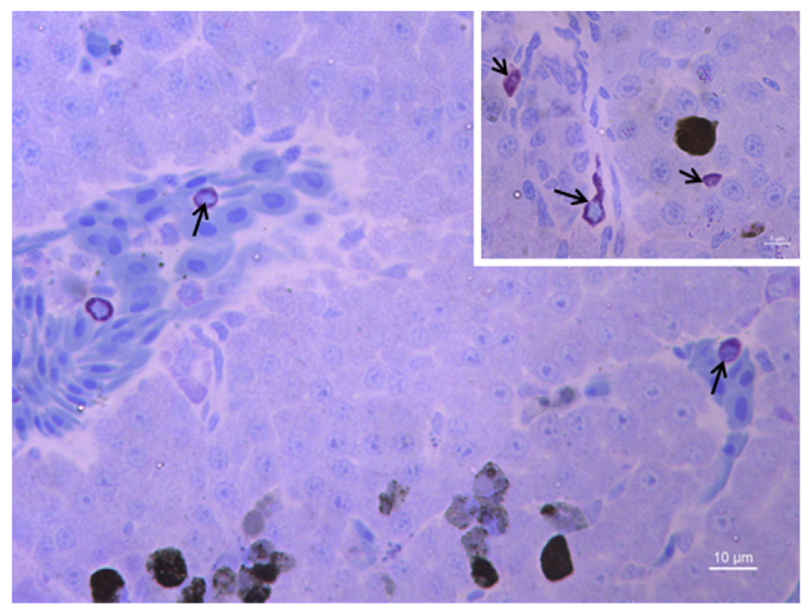

Fig. 6. Mast cell occurrence in the hepatic tissue of Physalaemus cuvieri. Coloration: Toluidine blue. 
(a-MSH) (Park et al., 2009; Videira et al., 2013), consequently, decreasing melanin synthesis in melanoma cells of mouse (Joo et al., 2015). Therefore, BaP may have affected the melanin synthesis of MMs and caused the melanin area of this cell to decrease.

After 13 days, although not significant, the melanin area of the MMs increased in both species. Regnault et al. (2016) stated that BaP hampers hepatic metabolism due to increased lipid content. This condition induces oxidative stress (Regnault et al., 2014, 2016), and since melanin has anti-oxidant function, MM melanin may have increased as a physiological response to BaP oxidative stress (Fanali et al., 2017).
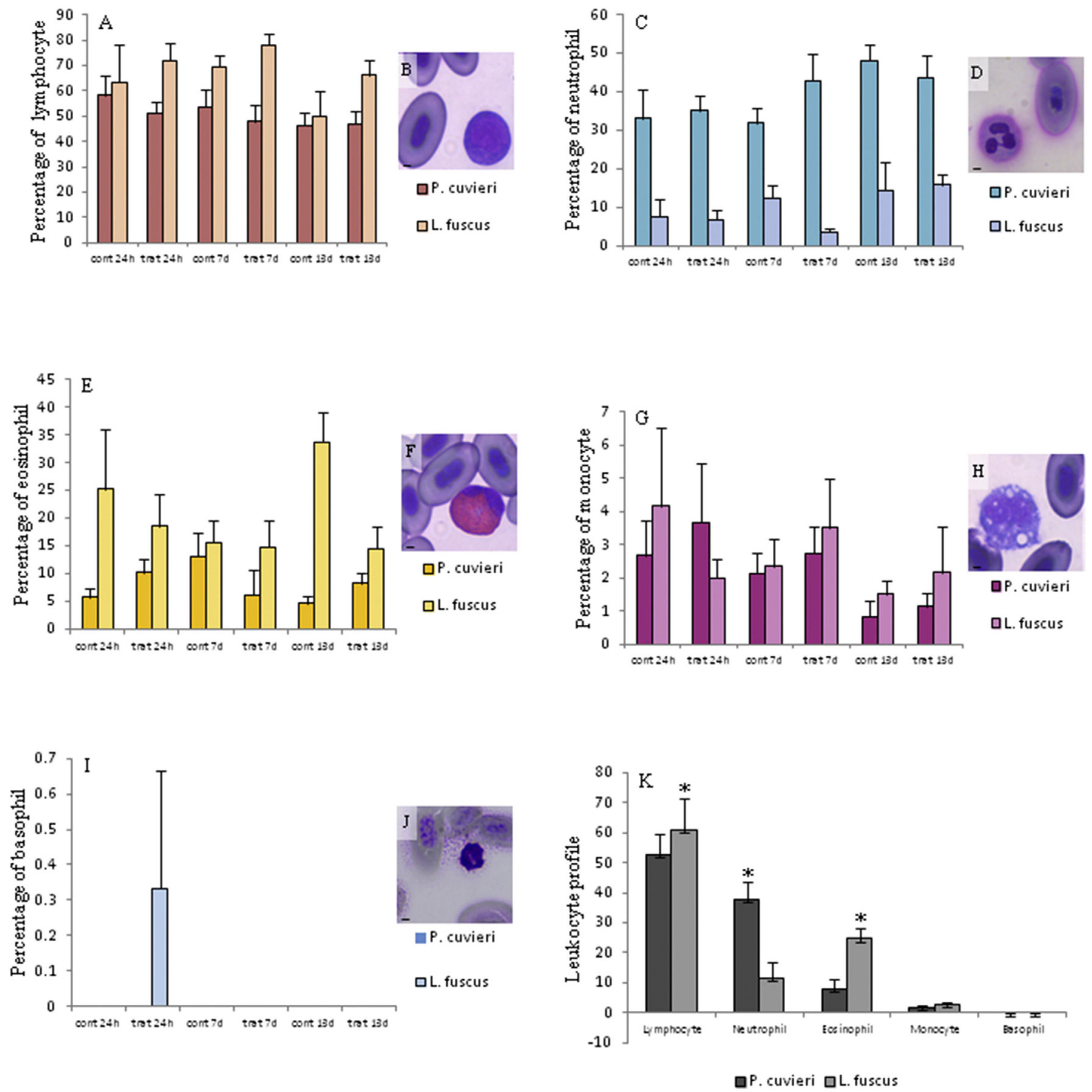

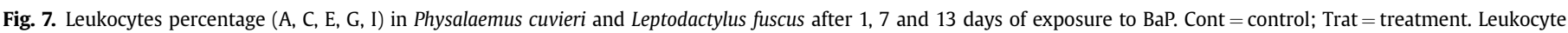

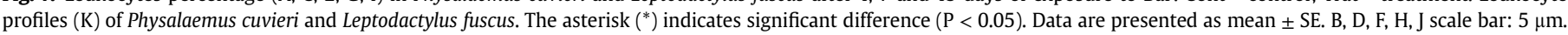


exposure. Franco-Belussi et al. (2014) showed that the number of mast cells in the E. nattereri testis tripled $12 \mathrm{~h}$ after LPS injection. This may have happened due to the infiltration of inflammatory and immune cell exudates in the interstitial region.

Ma et al. (2011) studied mice and showed that benzo[a]pyrene increased lymphocytes and enzymes involved in inflammation, and enlarged sinusoids as well. Möller et al. (2014) reported increased hepatic B and T lymphocytes of trout contaminated with BaP and concluded that the compound causes inflammation. In the liver of $P$. cuvieri and L. fuscus, BaP must have triggered an inflammatory response in the hepatic tissue, which increased the density of mast cells due to its protective function in inflammatory responses.

Leukocyte profile and benzo[a]pyrene effect on the percentage of leukocytes.

Despite the diversity of anurans, a great majority of the studies on their hematology are related to total cell count (erythrocytes and leukocytes) and morphometry of red blood cells (Cabagna Zenklusen et al., 2011), while detailed studies are lacking. The understanding of leukocyte responses of amphibians to diseases is limited (Campbell and Ellis, 2007), but is an important parameter for assessing organism health, demonstrating pollutant effects, and identifying biological changes caused by xenobiotics (Neta et al., 2015).

Some authors evidenced that in both fish and mammals, BaP and some of its metabolites, such as 7,8-BaP quinone (7,8-BPQ), BaP-7,8-dihydrodiol (BD), BaP-7,8-dihydrodiol-9,10-epoxide (BPDE), have an immunotoxic capacity (De Jong et al., 1999; Carlson et al., 2004; Gao et al., 2005; Phalen et al., 2014). Latif et al. (2010) studied birds and concluded that BaP has hematotoxic capacity due to decreasing total leukocytes, which may have resulted from the increased destruction rate of circulating leukocytes. The AhR expression induced P450 thus generating systemic oxidative stress (Dalton et al., 2002), which eventually impaired hematopoiesis (Latif et al., 2010). Nonetheless, in our study leukocyte remained unchanged, which may be related to hemato and cytotoxicity (Santacroce et al., 2015) that probably impaired the leukocyte response. Also, Matiasovic et al. (2008) concluded that unchanged lymphocytes, neutrophils, monocytes, and eosinophils may be due to high variances within individual groups, possibly explaining the unchanged leukocyte percentages in this study.

The leukocytes remained unchanged in P. cuvieri and L. fuscus, but the leukocyte profiles were different between both species, more specifically, lymphocytes, neutrophils, and eosinophils. The variability of red and white blood counts in amphibians is based on extrinsic factors such as temperature, diet, season, photoperiod and intrinsic factors such as species, gender, and lifestyle (Heatley and Johnson, 2009). As observed in our work, lymphocytes are the most abundant leukocytes in both P. cuvieri and L. fuscus species of anurans, similarly to Lithobates catesbeianus (Cathers et al., 1997) and Polypedates teraiensis (Das and Mahapatra, 2014). However, neutrophil is the most abundant leukocyte in Bufo marinus (Cannon et al., 1987) and Bufo americanus (Forbes et al., 2006). Heatley and Johnson (2009) argue that a conspecific animal or of the same genus can be sampled for comparison to minimize extrinsic and intrinsic variability for better hematological interpretation of amphibians.

Our results call the need for employing species of the same sex, feeding habits and sampling time period to minimize errors arising from interpretation of the data given the great variability of leucocytes.

\section{Conclusion}

Although there are particularities among species, BaP acts similarly in the body of the both species, which can be observed by the cellular alterations, like increased MN frequency and mast cell density, and decreased MMs area. These changes may trigger systemic processes in animals that are living in contaminated wet lands, like suppressing amphibian immune defenses, rendering them susceptible to additional chemical exposures like pesticides, metals and microbial infections. Other implication of this finding are that the exposure to BaP can affect the proper functioning of the cells due to the hepatotoxic, genotoxic, and immunotoxic characteristics of BaP. Then, BaP contamination can potentially impair the anurans life.

\section{Acknowledgements}

The authors thank Bruno S.L.Valverde for the assistance during the experiments, Ruth M.V.Kakogiannos for the manuscript translation and revision, Ivã G.L. for the manuscript revision. Thanks are also due to FAPESP for master fellowship (2014/07466-8) to LZF and post-doctoral fellowship to LFB (2014/00946-4). To CNPq for fellowship to CO (305081/2015-2).

\section{References}

Agius, C., 1980. Phylogenetic development of melano-macrophage centers in fish. J. Zool. 191 (1), 11-31.

Agius, C., Roberts, R.J., 2003. Review: melano-macrophage centres and their role in fish patology. J. Fish. Biol. 26 (9), 499-509.

Bates, D., Maechler, M., Bolker, B., Walker, S., 2015. Fitting linear, mixed-effects models using lme4. J. Stat. Software 67, 1-48.

Blaustein, A.R., Han, B.A., Relyea, R.A., Johnson, P.T.J., Buck, J.C., Gervasi, S.S., Kats, L.B., 2011. The complexity of amphibian population declines: understanding the role of cofactors in driving amphibian losses. Ann. N. Y. Acad. Sci. 1223 (1), 108-119.

Bolker, B.M., Brooks, M.E., Clark, C.J., Geange, S.W., Poulsen, J.R., Stevens, M.H.H. White, J.-S.S., 2009. Generalized linear mixed models: a practical guide for ecology and evolution. Trends Ecol. Evol. 24 (3), 127-135.

Brandt, C.A., Becker, J.M., Porta, A., 2002. Distribution of polycyclic aromatic hydrocarbons in soils and terrestrial biota after a spill of crude oil in Trecate. Italy. Environ. Toxicol. Chem. 21 (8), 1638-1643.

Buhler, D.R., Williams, D.E., 1988. The role of biotransformation in the toxicity of chemicals. Aquat. Toxicol. 11 (1-2), 19-28.

Burlibaşa, L., Gavrilă, L., 2011. Amphibians as model organisms for study environmental genotoxicity. Appl. Ecol. Environ. Res. 9 (1), 1-15.

Cabagna Zenklusen, M.C., Lajmanovich, R.C., Attademo, A.M., Peltzer, P.M., Junges, C.M., Fiorenza Biancucci, G., Bassó, A., 2011. Hematología y citoquímica de las células sanguíneas de Rhinella fernandezae (Anura: Bufonidae) en Espinal y Delta-Islas del río Paraná, Argentina. Rev. Biol. Trop. 59 (1), 17-28.

Cakıc1, Ö., 2015. Histopathologic changes in liver and kidney tissues induced by carbaryl in Bufotes variabilis (Anura: Bufonidae). Exp. Toxicol. Pathol. 67 (3), 237-243.

Campbell, T.W., Ellis, C.K., 2007. Hematology of amphibians. In: Avian and Exotic Animal Hematology and Cytology. Blackwell Publishing, Ames (IA).

Candioti, J.V., Natale, G.S., Soloneski, S., Ronco, A.E., Larramendy, M.L., 2010. Sublethal and lethal effects on Rhinella Arenarum (Anura, Bufonidae) tadpoles exerted by the pirimicarb-containing technical formulation insecticide Aficida ${ }^{\circledR}$. Chemosphere 78 (3), 249-255.

Cannon, M.S., Sampson, H.W., Kapes, E.D., 1987. The blood leukocytes of Bufo marinus: a light, phase-contrast, and histochemical study. Can. J. Zool. 65 (6), $1445-1453$.

Carlson, E.A., Li, Y., Zelikoff, J.T., 2004. Suppressive effects of benzo [a] pyrene upon fish immune function: evolutionarily conserved cellular mechanisms of immunotoxicity. Mar. Environ. Res. 58 (2), 731-734.

Caruso, M.S.F., Alaburda, J., 2008. Hidrocarbonetos policíclicos aromáticos - benzo(a)pireno: uma revisão. Ver. Inst. Adolfo. Lutz. 67 (1), 1-27.

Cathers, T., Lewbart, G.A., Correa, M., Stevens, J.B., 1997. Serum chemistry and hematology values for anesthetized American bullfrogs (Rana catesbeiana). J. Zoo Wildl. Med. 28, 171-174.

Cesarini, J.P., 1996. Melanins and their possible roles through biological evolution. Adv. Space Res. 18 (12), 35-40.

Chovatiya, R., Medzhitov, R., 2014. Stress, inflammation, and defense of homeostasis. Mol. Cell. 54 (2), 281-288.

Collins, J.F., Brown, J.P., Dawson, S.V., Marty, M.A., 1991. Risk assessment for benzo[a] pyrene. Regul. Toxicol. Pharmacol. 13 (2), 170-184.

Conrad, J., 2010. Amphibians. - retrieved from the backyard nature website at. http//:www.backyardnature.net/amphibs.htm.

Costa, J., Ferreira, M., Rey-Salgueiro, L., Reis-Henriques, M.A., 2011. Comparision of the waterborne and dietary routes of exposure on the effects of Benzo(a)pyrene on biotransformation pathways in Nile tilapia (Oreochromis niloticus). Chemosphere 84 (10), 1452-1460. 
Crawley, M.J., 2012. The R Book. John Wiley \& Sons, London.

Dalton, T.P., Puga, A., Shertzer, H.G., 2002. Induction of cellular oxidative stress by aryl hydrocarbon receptor activation. Chem. Biol. Interact. 141 (1), 77-95.

Das, M., Mahapatra, P.K., 2014. Hematology of wild caught Dubois's tree frog Polypedates teraiensis, Dubois, 1986 (Anura: Rhacophoridae). Sci. World J. 2014.

De Jong, W.H., Kroese, E.D., Vos, J.G., Van Loveren, H., 1999. Detection of immunotoxicity of benzo [a] pyrene in a subacute toxicity study after oral exposure in rats. Toxicol. Sci. 50 (2), 214-220.

De Oliveira, C., Franco-Belussi, L., Fanali, L., Santos, L., 2017. Use of melaninpigmented cells as a new tool to evaluate effects of agrochemicals and other emerging contaminants in brazilian Anurans. Ecotoxicology and Genotoxicology: Non-traditional Terrestrial Models 32, 125.

Fanali, L.Z., de Lacerda Valverde, B.S., Franco-Belussi, L., Provete, D.B., de Oliveira, C. 2017. Response of digestive organs of Hypsiboas albopunctatus (Anura: Hylidae) to benzo $[\alpha]$ pyrene. Amphib-Reptil 38, 175-185.

Fishelson, L., 2006. Cytomorphological alterations of the thymus, spleen, headkidney, and liver in cardinal fish (Apogonidae, Teleostei) as bioindicators of stress. J. Morphol. 267 (1), 57-69.

Forbes, M.R., McRuer, D.L., Shutler, D., 2006. White blood cell profiles of breeding American toads (Bufo americanus) relative to sex and body size. Comp. Clin. Pathol. 15 (3), 155-159.

Fortin, F., Bonvalot, Y., Pham, T.C.V., Ouellet, N., Ayotte, P., Viau, C., Lemieux, N., 2015 Biomarkers of genotoxicity measured in human lymphocytes exposed to benzo [a]pyrene: aneugenic effect, and involvement multiple primary DNA lesions. Integr. Pharm. Toxicol. Gentoxicol 1 (1), 21-32.

Fournie, J.W., Summers, J.K., Courtney, L.A., Engle, V.D., 2001. Utility of splenic macrophage aggregates as an indicator of fish exposure to degraded environments. J. Aquat. Anim. Health 13 (2), 105-116.

Fournier, D.A., Skaug, H.J., Ancheta, J., Ianelli, J., Magnusson, A., Maunder, M. Nielsen, A., Sibert, J., 2012. AD Model Builder: using automatic differentiation for statistical inference of highly parameterized complex nonlinear models Optim. Meth. Software 27, 233-249.

Franco-Belussi, L., Castrucci, A.M.D.L., de Oliveira, C., 2013. Responses of melanocytes and melanomacrophages of Eupemphix nattereri (Anura: Leiuperidae) to $\mathrm{Nle}^{4}, \mathrm{D}-\mathrm{Phe}^{7}-\alpha$-melanocyte stimulating hormone and lipopolysaccharides. Zoology 116 (5), 316-324.

Franco-Belussi, L., Leite, G.B., Freitas, J.S., de Oliveira, C., 2014. Morphological effects of bacterial compounds on the testes of Eupemphix nattereri (Anura). Anim. Biol. 64 (3), 261-275.

Franco-Belussi, L., Sköld, H.N., de Oliveira, C., 2016. Internal pigment cells respond to external UV radiation in frogs. J. Exp. Biol. 219 (9), 1378-1383.

Gao, J., Voss, A.A., Pessah, I.N., Lauer, F.T., Penning, T.M., Burchiel, S.W., 2005. Ryanodine receptor-mediated rapid increase in intracellular calcium induced by 7 8-benzo (a) pyrene quinone in human and murine leukocytes. Toxicol. Sci. 87 (2), 419-426.

Grinfeld, S., Jaylet, A., Siboulet, R., Deparis, P., Chouroulinkov, I., 1986. Micronuclei in red blood cells of the newt Pleurodeles waltl after treatment with benzo(a) pyrene: dependence on dose, length of exposure, posttreatment time, and uptake of the drug. Environ. Mutagen. 8 (1), 41-51.

Harris, K.A., Yunker, M.B., Dangerfield, N., Ross, O.S., 2011. Sediment-associated aliphatic and aromatic hydrocarbons in coastal British Columbia, Canada: concentrations, composition, and associated risks to protected sea otters. Environ. Pollut. 159 (10), 2665-2674.

Heatley, J.J., Johnson, M., 2009. Clinical technique: amphibian hematology: a practitioner's guide. J. Exot. Pet Med. 18 (1), 14-19.

Jiao, L., Zheng, G.J., Minh, T.B., Richardson, B., Chen, L., Zhang, Y., Yeung, L.W. Lam, J.C.W., Yang, X., Lam, P.K.S., Wong, M.H., 2009. Persistent toxic substances in remote lake and coastal sediments from Svalbard, Norwegian Arctic: levels, sources and fluxes. Environ. Pollut. 157 (4), 1342-1351.

Joo, D.H., Cha, H.J., Kim, K., Jung, M., Ko, J.M., Na, I.S., Ahn, K.J., 2015. Benzo (a) pyrene represses melanogenesis in B16F10 mouse melanoma cells. Mol. Cell. Toxicol. 11 (3), 349-355.

Juhasz, A.L., Naidu, R., 2000. Bioremediation of high molecular weight polycyclic aromatic hydrocarbons: a review of the microbial degradation of benzo[a] pyrene. Int. Biodeterior. Biodegrad. 45 (1), 57-88.

Kanaly, R.A., Harayama, S., 2000. Biodegradation of high-molecular-weight polycyclic aromatic hydrocarbons by bacteria. J. Bacteriol. 182 (8), 2059-2067.

Kenward, M.G., Roger, J.H., 1997. Small sample inference for fixed effects from restricted maximum likelihood. Biometrics 53, 983-997.

Kim, M., Kennicutt II, M.C., Yaorong, Q., 2008. Source characterization using compound composition and stable carbon isotope ratio of PAHs in sediments from lakes, harbor and shipping waterway. Sci. Total Environ. 389 (2), 367-377.

Larsson, B.S., 1993. Interaction between chemicals and melanin. Pigment. Cell. Melanoma Res. 6 (3), 127-133.

Latif, I.K., Karim, A.J., Zuki, A.B.Z., Zamri-Saad, M., Niu, J.P., Noordin, M.M., 2010 Pulmonary modulation of benzo [a] pyrene-induced hemato-and hepatotoxicity in broilers 1. Poultry Sci. 89 (7), 1379-1388.

Lauriano, E.R., Calò, M., Silvestri, G., Zaccone, D., Pergolizzi, S., Lo Cascio, P., 2012 Mast cells in the intestine and gills of the sea bream, Sparus aurata, exposed to a polychlorinated biphenyl, PCB126. Acta Histochem. 114 (2), 166-171.

Lenth, R.V., 2016. Least-squares means: the R package lsmeans. J. Stat. Software 69, $1-33$.

Loumbourdis, N.S., Vogiatzis, A.K., 2002. Impact of cadmium on liver pigmentary system of the frog Rana ridibunda. Ecotoxicol. Environ. Saf. 53 (1), 52-58.

Lüdecke, D., 2016. sjPlot: Data Visualization for Statistics in Social Science. R
Package Version 2.1.2. Available from: https://CRAN.R-project.org/ package $=$ sjPlot.

Luo, X.J., Chen, S.J., Mai, B.X., Sheng, G.Y., Fu, J.M., Zeng, E.Y., 2008. Distribution, source apportionment, and transport of PAHs in sediments from the Pearl River delta and the northern South China Sea. Arch. Environ. Contam. Toxicol. 55 (1), $11-20$.

Ma, J.Q., Liu, C.M., Qin, Z.H., Jiang, J.H., Sun, Y.Z., 2011. Ganoderma applanatum terpenes protect mouse liver against benzo $(\alpha)$ pyren-induced oxidative stress and inflammation. Environ. Toxicol. Pharmacol. 31 (3), 460-468.

Madureira, D.J., Weiss, F.T., Van Midwoud, P., Helbling, D.E., Sturla, S.J., Schirmer, K., 2014. Systems toxicology approach to understand the kinetics of benzo (a) pyrene uptake, biotransformation, and DNA adduct formation in a liver cell model. Chem. Res. Toxicol. 27 (3), 443-453.

Matiasovic, J., Leva, L., Maskova, J., Kummer, V., Faldyna, M., 2008. Effects of postnatal exposure to benzo [a] pyrene on the immunity of immature rats. Vet. Med.-Praha. 53 (2) 93.

Moen, E.L., Fricano-Kugler, C.J., Luikart, B.W., O'Malley, A.J., 2016. Analyzing clustered data: why and how to account for multiple observations nested within a study participant? PLoS One 11 (1), e0146721.

Möller, A.M., Korytáŕ, T., Köllner, B., Schmidt-Posthaus, H., Segner, H., 2014. The teleostean liver as an immunological organ: intrahepatic immune cells (IHICs) in healthy and benzo [a] pyrene challenged rainbow trout (Oncorhynchus mykiss). Dev. Comp. Immunol. 46 (2), 518-529.

Morillo, E., Romero, A.S., Madrid, L., Villaverde, J., Maqueda, C., 2008. Characterization and sources of PAHs and potentially toxic metals in urban environments of Sevilla (Southern Spain). Water Air Soil Pollut. 187 (1-4), 41-51.

Mouchet, F., Gauthier, L., Mailhes, C., Ferrier, V., Devaux, A., 2005. Comparative study of the comet assay and the micronucleus test in amphibian larvae (Xenopus laevis) using benzo (a) pyrene, ethyl methanesulfonate, and methyl methanesulfonate: establishment of a positive control in the amphibian comet assay. Environ. Toxicol. 20 (1), 74-84.

Neta, R.N.F.C., Sousa, D.B.P., de Macêdo Sobrinho, I.C., Horton, E.Y., De Almeida, Z.D.S., Tchaicka, L., de Sousa, A.L., 2015. Genotoxic and hematological parameters in Colossoma macropomum (Pisces, Serrasalmidae) as biomarkers for environmental impact assessment in a protected area in northeastern Brazil. Environ. Sci. Pollut. Res. 22 (20), 15994-16003.

Newman, S.H., Piatt, J.F., White, J., 1997. Hematological and Plasma Biochemical Reference Ranges of Alaskan Seabirds: Their Ecological Significance and Clinical Importance, pp. 492-504. Colon. Waterbird.

Ou, S., Zheng, J., Zheng, J., Richardson, B.J., Lam, P.K.S., 2004. Petroleum hydrocarbons and polycyclic aromatic hydrocarbons in the surficial sediments of Xiamen Harbour and Yuan Dan Lake China. Chemosphere 56 (2), 107-112.

Padrós, J., Pelletier, É., Ribeiro, C.O., 2003. Metabolic interactions between low doses of benzo[a]pyrene and tributyltin in arctic charr (Salvelinus alpinus): a longterm in vivo study. Toxicol. Appl. Pharmacol. 192 (1), 45-55.

Paetow, L.J., McLaughlin, J.D., Cue, R.I., Pauli, B.D., Marcogliese, D.J., 2012. Effects of herbicides and the chytrid fungus Batrachochytrium dendrobatidis on the health of post-metamorphic northern leopard frogs (Lithobates pipiens). Ecotoxicol. Environ. Saf. 80, 372-380.

Park, H.Y., Kosmadaki, M., Yaar, M., Gilchrest, B.A., 2009. Cellular mechanisms regulating human melanogenesis. Cell. Mol. Life Sci. 66 (9), 1493-1506.

Passantino, L., Santamaria, N., Zupa, R., Pousis, C., Garofalo, R., Cianciotta, A., Jirillo, E., Acone, F., Corriero, A., 2014. Liver melanomacrophage centres as indicators of Atlantic bluefin tuna, Thunnus thynnus L. well-being. J. Fish. Dis. 37 (3), 241-250.

Pastore, A.S., Santacroce, M.P., Narracci, M., Cavallo, R.A., Acquaviva, M.I., Casalino, E., Crescenzo, G., 2014. Genotoxic damage of benzo [a] pyrene in cultured sea bream (Sparus aurata L.) hepatocytes: harmful effects of chronic exposure. Mar. Environ. Res. 100, 74-85.

Pérez-Iglesias, J.M., de Arcaute, C.R., Nikoloff, N., Dury, L., Soloneski, S., Natale, G.S., Larramendy, M.L., 2014. The genotoxic effects of the imidacloprid-based insecticide formulation Glacoxan Imida on Montevideo tree frog Hypsiboas pulchellus tadpoles (Anura, Hylidae). Ecotoxicol. Environ. Saf. 104, 120-126.

Pérez-Iglesias, J.M., Franco-Belussi, L., Moreno, L., Tripole, S., de Oliveira, C., Natale, G.S., 2016. Effects of glyphosate on hepatic tissue evaluating melanomacrophages and erythrocytes responses in neotropical anuran Leptodactylus latinasus. Environ. Sci. Pollut. Res. 23 (10), 9852-9861.

Pérez-Iglesias, J.M., Soloneski, S., Nikoloff, N., Natale, G.S., Larramendy, M.L., 2015. Toxic and genotoxic effects of the imazethapyr-based herbicide formulation Pivot $\mathrm{H}^{\mathbb{R}}$ on montevideo tree frog Hypsiboas pulchellus tadpoles (Anura, Hylidae). Ecotoxicol. Environ. Saf. 119, 15-24.

Phalen, L.J., Köllner, B., Leclair, L.A., Hogan, N.S., van den Heuvel, M.R., 2014. The effects of benzo [a] pyrene on leucocyte distribution and antibody response in rainbow trout (Oncorhynchus mykiss). Aquat. Toxicol. 147, 121-128.

R Core Team, 2016. R: A language and environment for statistical computing. $\mathrm{R}$ Foundation for Statistical Computing, Vienna, Austria. URLhttps://www.Rproject.org/.

Regnault, C., Worms, I.A., Oger-Desfeux, C., MelodeLima, C., Veyrenc, S., Bayle, M.L., Reynaud, S., 2014. Impaired liver function in Xenopus tropicalis exposed to benzo[a]pyrene: transcriptomic and metabolic evidence. BMC Genom. 15 (1), 666.

Regnault, C., Willison, J., Veyrenc, S., Airieau, A., Méresse, P., Fortier, M., Brousseau, P., Raveton, M., Reynaud, S., 2016. Metabolic and immune impairments induced by the endocrine disruptors benzo [a] pyrene and triclosan in Xenopus tropicalis. Chemosphere 155, 519-527. 
Ribeiro, H.J., Procópio, M.S., Gomes, J.M.M., Vieira, F.O., Russo, R.C., Balzuweit, K., et al., 2011. Functionaldissimilarity of melanomacrophage centres in the liver and spleen from femalesof the teleost fish Prochilodus argenteus. Cell Tissue Res. 346 (3), 417-425.

Sadinski, W.J., Levay, G., Wilson, M.C., Hoffman, J.R., Bodell, W.J., Anderson, S.L. 1995. Relationships among DNA adducts, micronuclei, and fitness parameters in Xenopus laevis exposed to benzo [a] pyrene. Aquat. Toxicol. 32 (4), 333-352.

Santacroce, M.P., Pastore, A.S., Tinelli, A., Colamonaco, M., Crescenzo, G., 2015. Implications for chronic toxicity of benzo [a] pyrene in sea bream cultured hepatocytes: cytotoxicity, inflammation, and cancerogenesis. Environ. Toxicol. 30 (9), 1045-1062.

Santos, L.R.S., Franco-Belussi, L., Zieri, R., Borges, R.E., Oliveira, C., 2014. Effects of thermal stress on hepatic melanomacrophages of Eupemphix nattereri (Anura). Anat. Rec. 297 (5), 864-875.

Sayed, A.E.D.H., 2015. Hematotoxic and biochemical effects of UVA on the Egyptian toad (Bufo regularis). Int. J. Radiat. Biol. 92 (1), 35-41.

Shakoory, B., Fitzgerald, S.M., Lee, S.A., Chi, D.S., Krishnaswamy, G., 2004. The role of human mast cell-derived cytokines in eosinophil biology. J. Interf. Cytok. Res. 24 (5), 271-281.

Sibilano, R., Frossi, B., Calvaruso, M., Danelli, L., Betto, E., Dall'Agnese, A., Gri, G. 2012. The aryl hydrocarbon receptor modulates acute and late mast cell responses. J. Immunol. 189 (1), 120-127.

Sorensen, E.M.B., 1991. Metal Poisoning in Fish. CRC Press, Florida, p. 597.

Srogi, K., 2007. Monitoring of environmental exposure to polycyclic aromatic hydrocarbons: a review. Environ. Chem. Lett. 5 (4), 169-195.

Stark, A., Abrajano, T., Hellou, J., Metcalf-Smith, J.L., 2003. Molecular and isotopic characterization of polycyclic aromatic hydrocarbon distribution and sources at the international segment of the St. Lawrence River. Org. Geochem. 34 (2), 225-237.

Stogiannidis, E., Laane, R., 2015. Source characterization of polycyclic aromatic hydrocarbons by using their molecular indices: an overview of possibilities. In: Rev. Environ. Contam. Toxicol. Springer International Publishing, pp. 49-133.

Udroiu, I., 2006. The micronucleus test in piscine erythrocytes. Aquat. Toxicol. 79
(2), 201-204

Uetanabaro, M., Prado, C.P.A., Rodrigues, D.J., Gordo, M., Campos, Z., 2008, Guia de Campo dos Anuros do Pantanal e Planaltos do Entorno. Embrapa Pantanal-Livro científico (ALICE)

Van Veld, P.A., Patton, J.S., Lee, R.F., 1988. Effect of preexposure to dietary benzo [a] pyrene (BP) on the first-pass metabolism of BP by the intestine of toadfish (Opsanus tau): in vivo studies using portal vein-catheterized fish. Toxicol. Appl. Pharmacol. 92 (2), 255-265.

Videira, I.F.D.S., Moura, D.F.L., Magina, S., 2013. Mechanisms regulating melanogenesis. An. Bras. Dermatol. 88 (1), 76-83.

Wakx, A., Regazzetti, A., Dargère, D., Auzeil, N., Gil, S., Evain-Brion, D., Rat, P., 2016. New in vitro biomarkers to detect toxicity in human placental cells: the example of benzo [A] pyrene. Toxicol. Vitro 32, 76-85.

WHO. World Health Organization, 1998. Guidelines for Drinking-water Quality, second ed. World Health Organization, Geneva, pp. 123-152.

WHO World Health Oroanization IPCS, 1995. In: Environmental Health Criteria 165 - Inorganic Lead. Publish under the Joint Sponsorship of the United Nations Environment Programme, vol. 300. the International Labour Organization, and the World Health Organization.

Winkaler, E.U., Silva, A.D.G., Galindo, H.C. Martinez C.B.D.R, 2008. Biomarcadores histológicos e fisiológicos para o monitoramento da saúde de peixes de ribeirões de Londrina, Estado do Paraná. Acta. Scient. Biol. Sci. 23, 507-514.

Wolke, R.E., 1992. Piscine macrophage aggregates: a review. Annual. Ver. Fish. Dis. 2 91-108.

Zakaria, M.P., Takada, H., Tsutsumi, S., Ohno, K., Yamada, J., Kound, E., Kumata, H. 2002. Distribution of polycyclic aromatic hydrocarbons (PAHs) in rivers and estuaries in Malaysia: a widespread input of petrogenic PAHs. Environ. Sci. Technol. 36 (9), 1907-1918.

Zuasti, A., Jara, J.R., Ferre, C., Solano, F., 1989. Occurrence of melanin granules and melanosynthesis in the kidney of Sparus auratus. Pigm. Cell Res. 2 (2), 93-99.

Zuur, A.F., Ieno, E.N., Walker, N., Saveliev, A.A., Smith, G.M., 2009. Mixed Effects Models and Extensions in Ecology. Springer, New York. 